\title{
TURNING GLOBALIZATION 4.0 INTO A REAL AND SUSTAINABLE SUCCESS FOR ALU STAKEHOLDERS
}

\author{
Ivo Pezzuto
}

* The International School of Management (ISM), France

Contact details: The International School of Management (ISM), 17, boulevard Raspail, 75007 Paris, France

\begin{abstract}
OPEN ACCESS
How to cite this paper: Pezzuto, I. (2019). Turning globalization 4.0 into a real and sustainable success for all stakeholders. Journal of Governance \& Regulation, 8(1), 8-18. http://doi.org/10.22495/jgr_v8_il_pl

Copyright @ 2019 The Authors
\end{abstract}

This work is licensed under the Creative Commons Attribution 4.0 International License (CC BY 4.0)

http://creativecommons.org/licenses/by/ $\underline{4.0 /}$

ISSN Print: 2220-9352

ISSN Online: 2306-6784

Received: 01.12 .2018

Accepted: 11.01.2019

JEL Classification: E44, E58, E71, F01, I32 DOI: $10.22495 /$ jgr_v8_il_pl

\begin{abstract}
The paper aims to provide an overview of the major opportunities and challenges of the fourth phase of globalization in the current macro scenario characterized by a high level of economic and geopolitical complexity and uncertainty. The assumptions and results reported in this work are based mostly on the judgmental opinion of the author and on his critical analysis of macroeconomic data and global trends. The author of the paper is a seasoned chief economic advisor and professor of global economics and disruptive innovation. Forecasting global market trends and future scenarios in a highly unpredictable business environment is always a complex task which cannot be undertaken simply relying on quantitative research techniques based on historical datasets since the past is not always a good predictor of future events. The qualitative approach adopted for this research is based on multiple forms of data sources and the following activities: (1) identification of the key forces and trends in the environment (i.e. environmental scanning); (2) assessing the driving forces and trends by importance and uncertainty; (3) envisioning potential alternative scenarios; and (4) assessing the potential implications of each trend and scenario. The result of this analysis confirms the central role that technological development is likely to have in the near future as a major driver of disruptive change in the economic and social models of many countries and leads to the conclusion that the groundbreaking and disruptive innovations of the future should be perceived as a potential opportunity and not just as a threat by stakeholders in the international community.
\end{abstract}

Keywords: Globalization, Sustainability, Creating Shared Value, Complexity and Uncertainty, Macro Strategy Analysis, Technological Innovation, Social Inclusion, Global Competitiveness, International Business

\section{INTRODUCTION}

Engaging in International business these days can be very exciting for dynamic, highly competitive, and innovative firms and startups thanks to a vibrant and highly-interconnected global business environment; eagerly driven knowledge-sharing communities, and the ease of access to smart and seamless enabling technologies.

The innovation potential at the core of today's revolutionary smart technologies and their application in lean startups, agile business models, and groundbreaking digital transformation programs seem to benefit of the "Creative Destruction" power that was first advocated by
Joseph Schumpeter (Schumpeter, 1911) as a catalyst for the disruption of entire industries.

Despite the rising threat to the global economy of protectionism, populism, anti-globalization and anti-immigration movements and the social and economic concerns about macroeconomic imbalances and other serious challenges, it seems that a Globalization 4.0, after all, is still achievable, as claimed by Klaus Schwab (2018).

Among these challenges notable ones include: the potential disruptive impact on the labor market of groundbreaking technological innovations; public/federal and corporate debt overhang; high levels of leverage in the corporate world; distressed assets; red tape; uncertainties about the pace of central banks' monetary policy normalization, the 
risk of falling asset prices and assets' valuations due to "quantitative tightening" (tighter money supply), and a potential liquidity squeeze in the financial markets which might cause a potential "credit crunch" in the commercial private sector through a reduction of bank lending due to tighter regulatory requirements for risky assets versus the regulatory rules set for risk-free government bonds. More in general, a potential risk-off scenario in the future might lead to more cautious lending and investment strategies for riskier asset classes and to a liquidity dry-up. Other relevant potential future challenges may include the following ones: rising global macroeconomic imbalances, and in particular, the massive imbalances accumulated between the intraregional central banks in Europe as reported by the TARGET2 system (Figure 1), with the risk of a potential deterioration in the Eurozone of collateral values, which might trigger potential risks for the creditors of the TARGET2 imbalances. Still, other relevant risk factors may include: rising interest rates and debt sustainability issues; the tendency of some banks to have a higher balance sheet gearing than those in other jurisdictions; and a potential spillover-effect of banking crises to the global banking sector since banks are highly connected to the global banking system through interbank exposure and derivative markets, thus a potential systemic risk in one geographical region can be easily transmitted to other banking systems. Furthermore, central banks might also find themselves in a potentially challenging position as governments' debt traps might continue to grow in some countries over the years while economic growth and productivity improvements in the same economies might remain stagnant. Finally, a few additional potential risks in the future might be related to the following circumstances: aging societies and challenges related to the sustainability of the retirement systems; risks of global economic slowdown and flattening (or in some cases inverted) yield curves; rising inequality and sluggish improvements in social mobility; geopolitical tensions and the risk of trade tensions, trade wars, and cyberattacks; climate change and ecological sustainability issues (Macleod, 2019).

Figure 1. TARGET2 Balances (Billion euros)

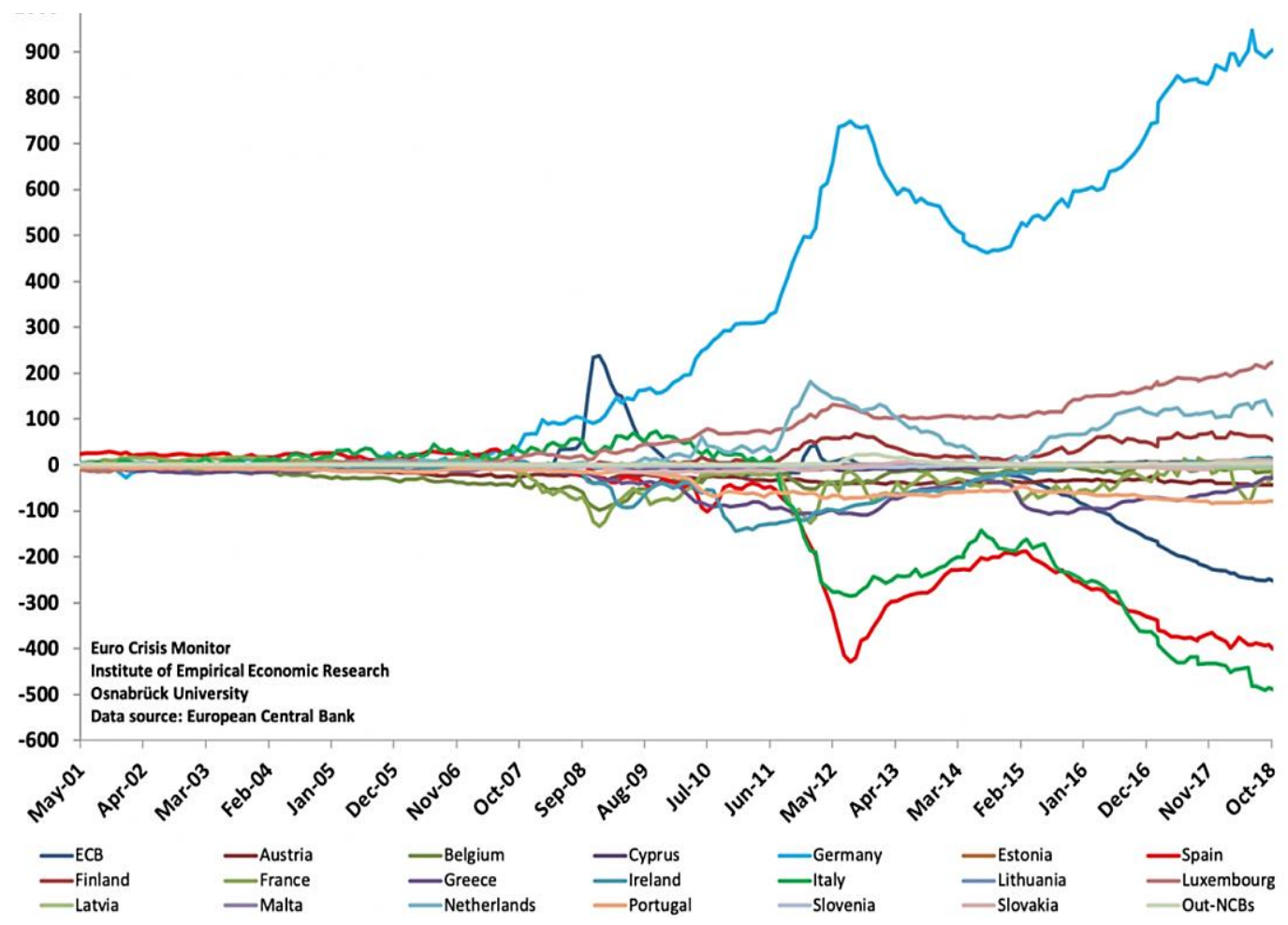

Source: European Central Bank 2018.

According to Klaus Schwab (2018) of the World Economic Forum, the solution to these challenges lies in bold reforms to be undertaken by the international community in order to build a better future for all stakeholders. These reforms should be driven by a shared vision and sense of purpose; courage; engagement, and the adoption of a new cooperative approach. In practice, the author advocates a new approach to global governance and a new mindset to promote "new global norms, standards, policies, and conventions" inspired by environmental sustainability and social inclusiveness, that may "safeguard the public trust" (Schwab, 2018).
Scholars such as Michael Porter and Mark Kramer $(2011,2018)$ argue that there seem to be an urgent need for business to rethink its role in society by incorporating a social purpose into core competitive strategy. For this scope, these scholars have proposed the concept of Creating Shared Value (CSV), which is an innovative "approach that treats social issues as a source of economic opportunity and competitive differentiation for business, rather than a social obligation or cost of doing business" (Porter \& Kramer, 2011; 2018). Thus, ultimately, the authors encourage forward-thinking firms to embrace the CVS approach since it is a source of competitive advantage that creates measurable 
social impact for society at large scale and economic benefits for the business, "unlocking the next wave of business innovation and growth" (Porter \& Kramer, 2011; 2018). The CVS approach is a different concept from CSR, sustainability, and philanthropy, since it aims to "become a powerful new movement to drive social progress on a global scale but also a central component of competitive strategy for companies" (Porter \& Kramer, 2011; 2018).

The structure of this paper includes a critical analysis of the major opportunities and challenges of the new era of globalization, stemming from the unprecedented opportunities in the markets driven by the emerging new technological innovations for businesses and consumers to the challenges of rising inequality, limited social mobility, and potential tail-risks in the financial markets. The paper provides detailed data, insightful figures, and fact-based analyses regarding the opportunities and challenges of the new era of globalization, which are also the result of the decisions and policies undertaken in the previous phases of globalization. Overall, the paper provides a broad perspective on the topic of globalization in the current era aiming to stimulate reflections and ideas for potential policy and governance improvements in order to make the new era of globalization a true success for all stakeholders.

\section{INSIGHTS, RESEARCH EVIDENCES, SCENARIOS, AND ANALYSES FOR DISCUSSION}

In the last decade, despite the benefits of sustained growth led mostly by the emerging and developing markets, a number of factors have contributed to increase the level of uncertainty, complexity, and volatility in the advanced economies which have ultimately affected households and firms' confidence in the sustainability of the existing economic and social model.

Among these factors critical ones are: the aftermath of the 2008 global financial crisis; the "Great Recession" and the social costs of the financial firms' bail-outs; a tough fiscal austerity in a number of countries; a growing distrust in the open markets mantra and neoliberal global order; massive liquidity injections in the financial markets by central banks after the financial crisis but also an increasing number of precarious workers at risk of poverty (i.e. in the EU - Figure 2) and wage stagnation for the average employee, despite recent salary improvements in some economies at or close to full employment (i.e. USA); reduction in health insurance, retirement, and welfare benefits, wealth loss; declining economic mobility for less educated and skilled employees in advanced economies; massive recourse to manufacturing off-shoring of lower add-value productions, reduction of excess production capacity in the home base for these labor-intensive productions, and environmental sustainability issues in developing markets; economic model shift in many countries from a production-oriented economy toward a serviceoriented economy; stagnant productivity increases in advanced economies; fiscal and regulatory arbitrage benefits (i.e. tax havens and secrecy jurisdictions) for the corporate world in the globalized marketplace; and fierce global competition and the unprecedented pace of an innovation-driven economy, which has produced winners and losers in the international arena (Pezzuto, 2013; 2014; 2017).

Figure 2. Share of working poor in all major EU economies (employed people at risk of poverty, \%)

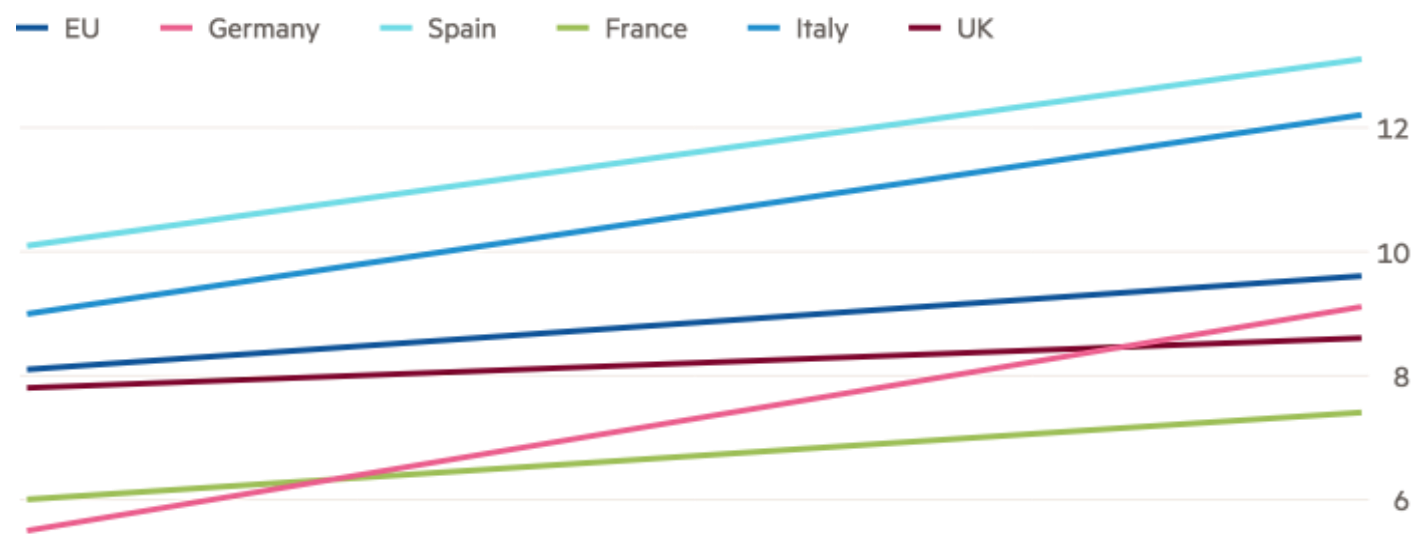

Note: Workers who live in a house hold with an income below $60 \%$ of the national average income.

Sources: Eurostat, @valentinaromei.

Alarming levels of sovereign debt, speculativegrade (Junk) bonds, and leveraged loans in the USA and other nations (i.e. shadow banking and opaque lending in the emerging and developing markets) have been accumulated in the past decade due to a prolonged period of low interest rates, ease of access to excess liquidity, favorable exchange rate against the US dollar for foreign markets (i.e. the so- called "global reserve currency"), and ultraexpansionary fiscal and monetary policies that have ultimately encouraged the adoption of a less rigorous fiscal discipline in a number of countries.

These high levels of debts have often been used by speculative grade firms of many industries to fund mergers and acquisitions, buyouts, dividends, or share buybacks. The IMF reports that while these 
highly leveraged loans have been rising to alarming levels, investors have been left with limited protections on these new loans since "covenant-lite" loans (loans with a deterioration in the quality of the covenants) have mushroomed, making up approximately $80 \%$ of new loans arranged by nonbank lenders in the U.S. in 2018, up from about $30 \%$ in 2007 (Nelson, 2018).

In the US, bank regulation is currently being relaxed and the quick rise of highly leveraged loans can turn out to be a particularly cumbersome challenge in case of an adverse market scenario or changing economic cycle. Former chair of the US Federal Reserve, Janet Yellen, has also recently raised a warning message on this matter claiming that there has been a "huge deterioration" in lending standards which could potentially lead to systemic risks associated with these loans. As reported in Figure 3, the rapid growth in the leveraged loan market is part of a boom in collateralized loan obligations (CLOs) which are often being built up by nonbank lenders (Nelson, 2018).

Figure 3. Outstanding US CLO market*

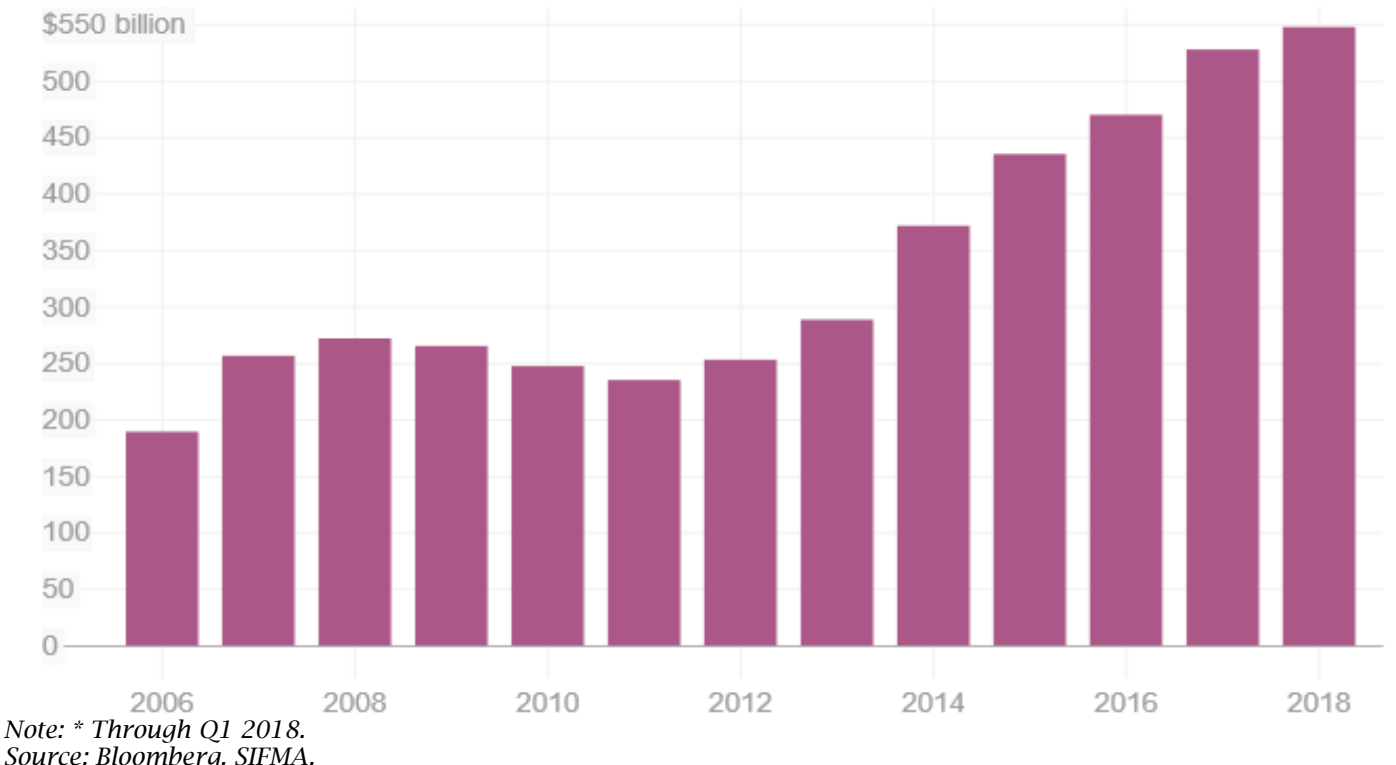

This is a particularly worrying evidence in a context of high and rising speculative-grade corporate debt; stretched equity markets valuations; highly correlated asset classes; global markets' interdependence; growing imbalances; massive increase in leveraged loans and loose and abundant credit availability to corporate borrowers by nonbank lenders.

In a rapidly changing business environment characterized by rising interest rates, central banks' monetary policy normalization, trade wars threats, and geopolitical tensions, weaker economies are under considerable pressures. To remain competitive, they may continue to pursue debt payment extensions (i.e. dollar-denominated debt), currency devaluations, aggressive fiscal stimuli, reduced fiscal discipline, loose monetary policies, loose credit standards, or they may decide to transfer leveraged loans' credit risk to investors through the securitizations process (i.e. CLOs). Thus, regulators should remain vigilant of a potential build-up of risks related to such practices, and in particular to the risk of potential bubbles triggered by a widespread expansion of infrastructure investments, leveraged loans, securitizations, and CLOs.

It is no surprise that all these alarming signs of increased uncertainty, complexity, and volatility may have a strong and lasting impact on consumers, investors, and firms' confidence levels and propensity to consumer and invest. If not properly monitored and controlled by the multilateral institutions and leading international regulators and supervisory authorities, these potential tail-risk factors may eventually escalate into new systemic risks and have a spill-over effect across markets due to severe macroeconomic imbalances and financial instability risks, unless a proper fiscal backstop mechanism and coordinated global governance is ensured.

As a consequence, in an adverse scenario, potential systemic risks may occur triggered by sovereign risk and the need for debt relief of distressed debt; or triggered by bank risk as highly leveraged firms may default on their corporate debt; or triggered by the vicious circle between bank risk and sovereign debt risk.

Under this severe adverse scenario, banks may be forced to rapidly clean up their balance sheets (i.e. NPL - Non-Performing Loans); undertake tough recapitalizations; seek governments' support and guarantees for troubled assets; accept debt restructuring agreements and "Bail-In" rules; accept constraints to dividend distributions; seek the intervention of a Crisis Resolution Fund, a financial stability mechanism (i.e. ESM), or of a "Bad Bank" for their rescue; seek support from Multilateral Institutions such as the International Monetary Fund (IMF); or more simply, they may transfer most of their crisis resolution costs on their own bondholders through the sale of subordinated debentures/bonds (or "bail-able bonds" capable of absorbing the losses), or they may sale subordinated debt repackaged into asset-backed securities (i.e. ABS, CLOs) to global investors.

In the past decade, all these potential risk factors have raised major concerns in taxpayers and investors; have reduced their trust in the leaders, 
and have encouraged them to seek more protection for their jobs, unemployment insurance benefits, and personal savings.

Supporters of protectionism claim that "free trade" and an unchecked model of globalization have damaged their economies and generated increased inequality. They question the widespread diffusion of unfair practices in global trade, an unfit model of multilateralism, excess of governments' interventions and subsidies to foreign firms, dumping practices, intellectual property theft, artificial currency devaluations, looser environmental protection standards, looser human rights and labor market laws in foreign markets. They even question the validity of the international trade agreements (i.e. the Trans-Pacific Partnership TPP; the North American Free Trade Agreement NAFTA; the Comprehensive Economic and Trade Agreement - CETA; the Transatlantic Trade and Investment Partnership - TTIP; and the EU and the future Post-Brexit Trade Agreement) and the credibility and survival of the World Trade Organization (WTO).

All these complex factors have fueled job insecurity, frustration, and public distrust towards the élites. Anti-establishment movements have risen over the years in a number of countries in response to what they claimed to be incapable élites, unable to create adequate safety nets and social mobility opportunities for millions of people dislocated by prolonged periods of economic crises, stagnant growth, changing labor market structure, and disruptive technological changes (OECD, 2018).

Some authors have dubbed this complex, challenging, and vulnerable business environment in the global economy as the "New Normal." An OECD study has reported that "Income inequality in OECD countries is at its highest level for the past halfcentury. The average income of the richest $10 \%$ of the population is about nine times that of the poorest $10 \%$ across the OECD, up from seven times 25 years ago. Uncertainty and fears of social decline and exclusion have reached the middle classes in many societies" (OECD, 2014; 2018).

Furthermore, a recent study published in the Journal Nature (Kohler et al., 2017) reports that societies with high inequality also have low social mobility and that the downward trend is not proved only by the decline in Gini scores (i.e. Relative Gini coefficient, in which a score of 0 represents total equality and a score of 1 represents total inequality), but also by the Absolute Gini index (defined as the Relative Gini multiplied by the mean income) which indicates that inequality has exploded over the past few decades, from 0.57 in 1988 to 0.72 in 2005 (Wade, 2005), along with a sharp increase in anger, violence, and social unrest (Kohler et al., 2017).

According to an OECD study on inequality, "the main mechanism through which inequality affects growth is by undermining education opportunities for children from poor socio-economic backgrounds, lowering social mobility and hampering skills development" (OECD, 2014).

There is no doubt that many less skilled and competitive people have been caught off guard, unprepared, or unable to react to the revolutionary and hectic rate of change of globalization and technological disruptions and that many have been unable to cope with the challenges of the "New Normal". Thus, a large number of these people have eventually surrendered to the idea that only a nostalgic return to the past could protect them from the risks of an unchecked model of globalization. Many, in fact, have been advocating more protectionism, more defense of local interests, and less globalism, thus confusing as correctly stated by Klaus Schwab, globalism for globalization (Schwab, 2018).

Yet, as shown in Figure 4, social mobility has indeed dramatically decreased in the past decades in a number of advanced economies probably due also to globalization, technological change, changes in the labor market and industry structure, and to inadequate economic and structural policies laid out by a number of governments (i.e. structural reforms designed to increase effective public spending, factors' productivity, average firm size, innovative skills, average employee's salary, R\&D investments and FDIs, cluster developments, and public-private sectors' collaborations). Figure 5 indicates that now only about half of 30-year-olds Americans make more money than their parents did at a similar age (Smith, 2018). For many, this downward social trend means the end of the "American Dream".

Figure 4. Share of wealth and income going to the richest 1 percent of individuals

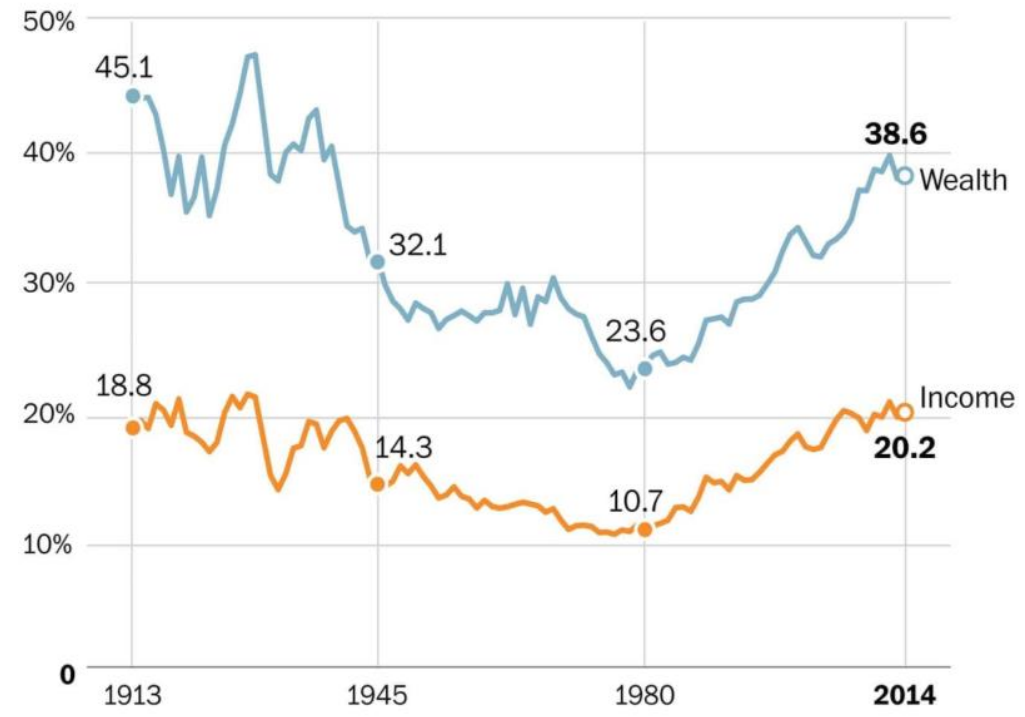

Source: Piketty et al., Word Wealth and Income Database. 
Figure 5. Social mobility in the USA (1970-2014)

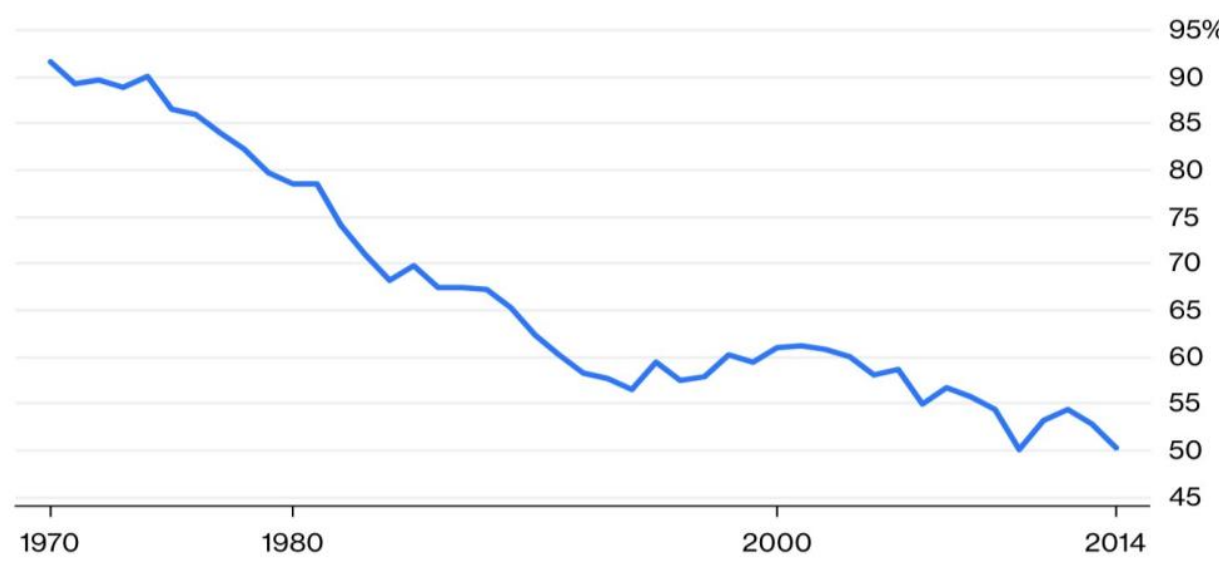

Note: Estimated probability of 30-year-old earning more than parents did.

Source: Equality of opportunity project.

Globalization has certainly improved in the past decades the employment rate on a global scale; living standards, wages, human rights, and the quality of national institutions and infrastructures of many emerging and developing markets, thanks also to massive increases in foreign direct investments (FDIs) and cluster developments. Thus, ultimately, globalization through its four waves (phases) has helped lift more than one billion people out of extreme poverty and has turned their economies into very attractive targets of firms growth strategies, thanks to the rise of a more knowledgeable, demanding, and educated fastgrowing middle class. Some of these markets are becoming innovative and high growth potential markets of the future.
Yet, an OECD study also indicates that "in emerging economies, such as China and India, a sustained period of strong economic growth has helped lift millions of people out of absolute poverty but the benefits of growth have not been evenly distributed and high levels of income inequality have risen further" (OECD, 2014; 2018).

Thus, in spite of the popularly acclaimed "convergence theory" which holds that, because poor countries grow at a faster rate than rich countries, over time the gap between the two will automatically diminish, currently the income gap (GDP per capita) and economic inequality between countries have not significantly decreased as indicated in Figure 6.

Figure 6. GDP per Capita, Emerging vs. Developed markets

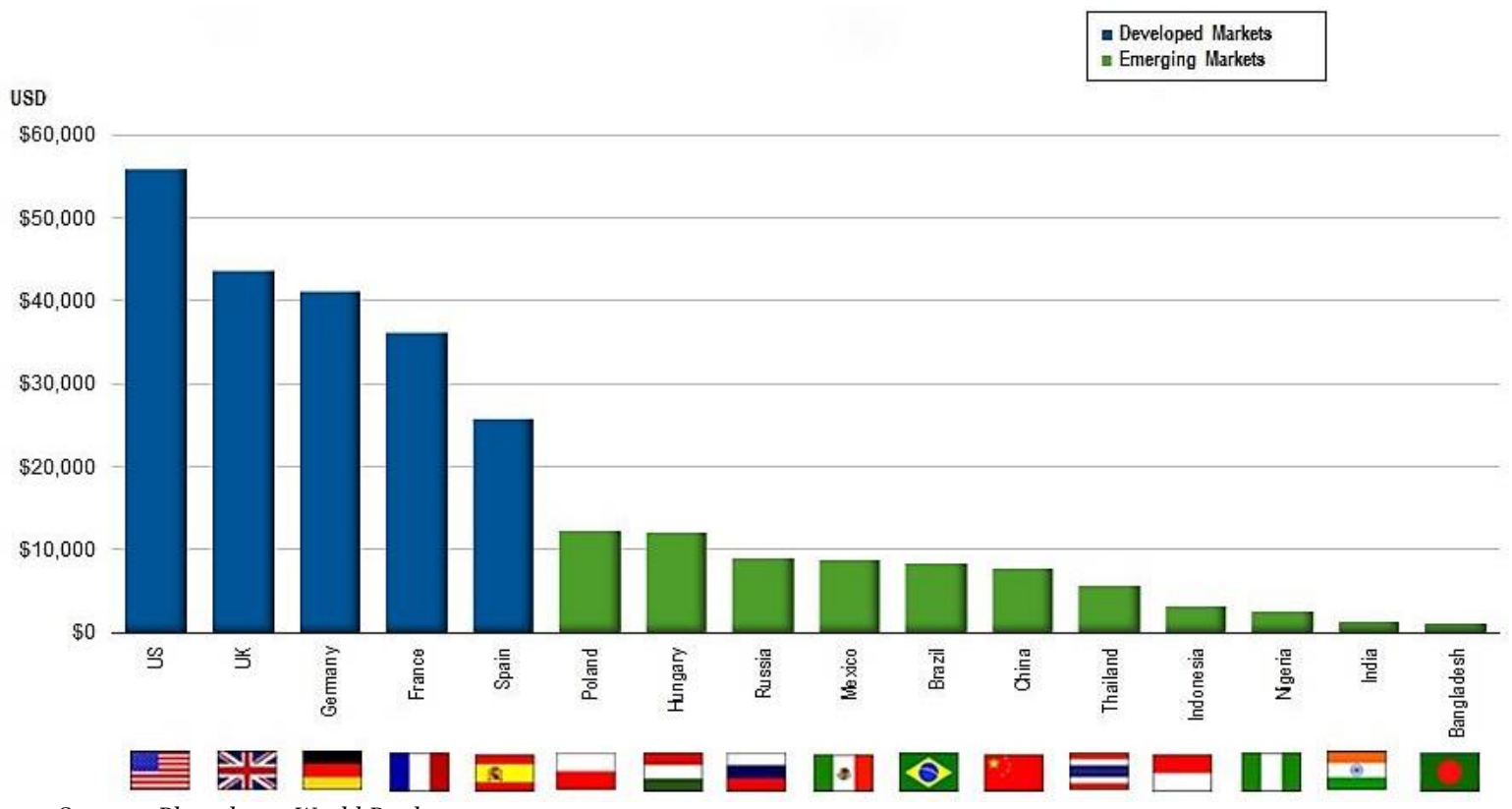

Sources: Bloomberg, World Bank.

Nevertheless, as explained by scholarly research, today many emerging and developing markets are no longer selected by international firms just for the scope of exploiting their cheap labor, low manufacturing costs, fiscal incentives, and regulatory arbitrages. Innovative and forwardlooking Transnational (or "Glocal") firms are instead adopting new internationalization strategies focused 
on achieving worldwide competitive advantages pursuing efficiency, flexibility, and learning goals simultaneously.

Hill and Hult (2018), argue that firms aim to achieve Transnational benefits through a dispersed, interdependent and specialized global configuration of activities, assets, value networks, and Industry 4.0 technologies and capabilities (global value chains) in order to gain and retain long-term sustainable competitive advantages and a higher innovation potential (Hill \& Hult, 2018).

As claimed by Schwab (2018), a wise and enlightened global governance of the Globalization 4.0 and Fourth Industrial Revolution (4IR) can help "forge a new social compact between citizens and their leaders so that everyone feels secure enough at home to remain open to the world at large" otherwise, "the ongoing disintegration of our social fabric could ultimately lead to the collapse of democracy" (Schwab, 2018).

Firms engaging in international business today are faced with the challenging task of envisioning, developing, and executing ambitious innovation-led growth strategies, in order to keep up to speed with the current fast-paced innovation-driven economy, while also keeping "on their radar" the growing uncertainty related to rising risks of social unrest and geopolitical tensions in multiple global economies driven by rising economic divergence, inequality, the perceived demise of multilateralism, and sharp declines of the Social Progress Index (SPI).

Despite the evident and serious sustainability challenges for our global community, however, the lesson of Joseph Schumpeter (Schumpeter, 1911) on innovation and "Creative Destruction" as major drivers of growth, prosperity, and progress should not be forgotten. Global leaders should pursue plans and long-term economic development goals for the international community inspired by the vision of a more sustainable and inclusive society and protected natural environment but without penalizing the true drivers of economic and social development which are: imagination, problem solving, R\&D, enabling technological innovations, industrial clusters, highly engaged and mutually supportive value networks and trusted communities of experts, business friendly ecosystems, growth strategies that encourage social inclusion and higher living standards for all, and efficient and innovative sources of capital.

Analyzing over the years the rapid rate growth of leading US Tech Giants (i.e. Apple, Alphabet, Cisco, Microsoft, Oracle, Amazon, Facebook, Netflix) and Chinese Tech Giants (i.e. Baidu, Alibaba, Tencent), and their impressive market capitalization, it results quite clear the significant contribution provided by technological innovation and experimentation to the value creation process of these firms and their shareholders. These trends are likely to progress in the future unless protectionism, populism, trade disputes, financial crises, and geopolitical instability may eventually derail the existing world order. Other factors that may affect in the future the strong performance of these tech giants include: a slower global economy; changes in consumer preferences, tastes, aspirations, values, lifestyles, and brand loyalty engagement; overlooked market segments; incumbents chasing higher profitability in moredemanding market segments that innovate faster than their customers' needs evolve (i.e. 'technology overshoot'); innovative and agile startups and emerging firms with more efficient, disruptive, and scalable business models, supported by a technological shift, that close the innovation gap with global competitors and outperform their rivals with a better and more convenient value proposition (Christensen \& Raynor, 2013).

Looking at the 2018 Global Competitiveness Index 4.0 of the World Economic Forum (Figure 7), it reveals that the innovation powerhouses in the world remain those countries that have developed over the years strong innovation capabilities; that have allocated high level investments for R\&D and technological innovation as a percentage of the GDP; that have an adequate attitude towards entrepreneurial risk; that have competitive firms with scalable business models; that have good levels of public-private cooperation; that have the right corporate culture, flexibility, and organizational agility to adjust to rapidly changes in the business environment and to promote creativity by empowering employees and encouraging them to create, challenge and experiment; and that have developed advanced financial systems and venture capital expertise (WEF, 2018).

Figure 7. 2018 Global Competitiveness Index 4.0

\begin{tabular}{|c|c|c|c|}
\hline${ }^{*}$ Global Rank & Score $(0-100)$ & $\begin{array}{c}\text { Global Average } \\
\qquad\end{array}$ & Distance to Frontier \\
\hline 1. United States & 85.6 & & 14.4 \\
\hline 2. Singapore & 83.5 & & 16.5 \\
\hline 3. Germany & 82.8 & & 17.2 \\
\hline 4. Switzerland & 82.6 & & 17.4 \\
\hline 5. Japan & 82.5 & & 17.5 \\
\hline 6. Netherlands & 82.4 & & 17.6 \\
\hline 7. Hong Kong SAR & 82.3 & & 17.7 \\
\hline 8. United Kingdom & 82.0 & & 18.0 \\
\hline 9. Sweden & 81.7 & & 18.3 \\
\hline 10. Denmark & 80.6 & & 19.4 \\
\hline
\end{tabular}


More than ever before, innovation, and in particular, technological innovation, but also free trade, real-time information flow, and knowledge exchange are some of the main drivers of growth, productivity, competitiveness, and development in the global marketplace.

The following ones are some of the major forces and potential opportunities that are shaping global trends and future scenarios which are likely to generate positive and lasting impact on firms' value creation and countries' GDP per capita, in spite of the multiple and still difficult to predict potential risks and uncertainties of the new era of globalization (Atkinson, 2018; Pezzuto, 2017):

1) Digital revolution and technological breakthrough:

- Big data, artificial intelligence, computer vision, machine learning, natural language processing, and deep learning; speech, pattern, handwriting, and facial recognition; cognitive systems and multisensory interfaces; blockchain technology and its distributed peer-to-peer ledger of records;

- Virtual and augmented reality, bot and chatbots and online learning, intelligent digital assistant devices, artificial creativity, fuzzy logic, genetic algorithms, neural networks, intelligent agents, and data visualization;

- Digital transformation and cloud computing, cloud-based analytics platforms, cyberphysical systems, and edge technologies;

- Enhanced mobile broadband solutions, Internet of Things (IoT), mobile internet/apps, socia networks, ecommerce platforms, digital products, legal tech, fintech, regtech, robo advisers, cryptocurrency, mobile banking services, crowdfunding, and instant payment systems;

- Robotics and collaborative robots, drones, autonomous vehicles, electric vehicles (and the rise of metals required to produce lithium-ion batteries for electric vehicles such as cobalt, lithium and nickel). Hydrogen fuel cells vehicles, solar vehicles, VTOL (Vertical Take-Off and Landing) aircrafts, flying cars, lean manufacturing, smart factory, industry 4.0 projects, additive manufacturing, digital continuity, predictive maintenance, autonomous manufacturing system optimization, crowdsourcing, 3D printing, smart cities, and remote sensing satellites;

- Widespread diffusion of digital platforms such as Airbnb, Uber and Amazon, Alibaba.

2) Population ageing/demographics, social change:

- Rising internet usage and increasing connectedness; rise of individual choice in consumption decisions and fracturing of the mass market; rise of the individualism and decline of social cohesion; reduced trust in mainstream media; changes in the structure of the "traditional" family with single person households which are the fastestgrowing; cultural convergence and increasing extreme; the challenge of a rising immigration phenomenon; the emergence of public opinion as a revolutionary force; new approaches to education and the need for life-long learning.

3) Structural changes in the labor market:

- Increasing remote/smart working solutions and employees that want to work for an organization with a powerful social conscience and a social purpose.

4) Diffusion of innovative solutions to boost productivity and growth strategies:

- Lean start-ups, agile organizations, predictive maintenance and advanced analytics to reduce maintenance costs and increase uptime, automated operations, supply-chain optimization, pilot solutions, expansion of international greenfield infrastructure projects in developing and lowincome countries (i.e. China) and the simultaneous sale of diverse baskets of infrastructure loans to global investors through the "securitizations" process (i.e. having global investors buying infrastructure loans repackaged into securities) in order to free banks' capital to be redeployed into other greenfield infrastructure projects. Rapid diffusion of "IoT-enabled" products and services frameworks, disruptive innovations, and scalable business models based on high productivity improvement through technology. Fast growth of technology giants with strong free cash flow (FCF) in strategic industries of the future through synergic acquisitions (M\&A activities) of startups, unicorns, and innovative firms in order to expand their ecosystem and global competitiveness (i.e. online video and music streaming business, food delivery, logistics, renewable energies, driverless vehicles, automation, A.I., IoT and robotics technologies, ecommerce and social media platforms).

5) Focus on welfare sustainability, corporate social responsibility, creating shared value (CSV) strategies, impact investing and socially responsible investing (SRI) with Environmental, Social and Governance (ESG) criteria.

6) Climate change, resource scarcity, ecological constraints, green economy, circular economy, and renewable energies.

7) Disruptive utilities and agricultural innovations:

- Smart irrigation devices, water conservation technologies, soil sensors, drones collecting data and imagery proving analytics and reducing water, fertilizer, and fuel costs.

8) Changes in regulation/deregulation:

- Global diffusion of new regulatory frameworks designed to enable innovation-friendly environments to lure start-ups like in the case of the Sandbox idea;

- China's efforts to accelerate its regulatory approval of financial firms with majority stakes held by foreign investors in order to open its capital markets and create globally competitive banks and a more sustainable financial market;

- President Trump's Administration attempts to deregulate the financial markets and part of the post-crisis regulation introduced in 2010 (i.e. The Dodd-Frank Wall Street Reform and Consumer Protection Act) to sustain economic growth.

9) Increasing datification of people's lives (data utilization) and the challenges with data protection and privacy issues.

10) Slow improvement in closing gender pay gap and global gender gap index which requires a stronger commitment by global leaders and policymakers to advance with their gender, diversity, and social inclusion agendas.

11) Defense and security industry expansion and aerospace exploration: 
- AI-enabled military applications and defense robotics, drones using mobile satellite connectivity to access military clouds, Anti-satellite (ASAT) weapons, intelligence satellites and spy satellite, cyber and electronic warfare devices.

12) Shift in global economic power and political influence, and the advent of an increasingly multipolar international order:

- International trade tensions but also escalation of geopolitical tensions for research, innovation, economic, military and political dominance in the global arena. China's massive scale expansion of major infrastructure projects (granting collateralized loans to foreign countries) and its growing "soft power" influence through The One Belt, One Road Initiative (OBOR), in many countries and in particular in Eurasia and Africa (Strauss, 2018).

13) The rise of the sharing economy and disruptive innovations for improving social inclusion and eradicating poverty:

- Moving away from the physical possession of goods towards a more sustainable model of sharing goods (Airbnb); sharing good and experience (BlaBlaCar), reducing waste and underutilization of goods, and eradicating poverty (food industry, agriculture industry, i.e. the Indomie instant noodle in Nigeria); or improving the ecological impact on the environment and economic, social and environmental sustainability (Buchanan, 2019).

14) Rapid increase of urbanization.

15) Rising health-conscious segments of the population and rising attention on the application of A. I. and mobile technologies for personalized telemedicine services (remote delivery of healthcare services).

As stated by Paul Bakus, President of Corporate Affairs of Nestle, the future for international business and our society looks very promising thanks to the great innovation and growth potential provided by the digital revolution and the technological breakthroughs. The way forward for a more sustainable future for the international community can be well-summarized by his inspiring and visionary statement: "More or less all business started out with a social purpose of some kind... What's been lost in recent decades is the interconnectivity between the needs of society and the innovative dynamism of business... So, the future may look more like a rediscovery of this social purpose of business." (Atkinson, 2018).

Given the current scenario of fast-paced technological developments, innovation breakthroughs, and high level of automation, integration, and digital transformation of many firms, it seems quite likely that in the future a new model of economic growth and sustainability will eventually unfold. A model in which workers will spend less time on repetitive and boring tasks and more time on activities that machines may not perform equally well such as, "managing people, applying expertise, and communicating with others" (McKinsey Global Institute, 2017).

Activities that require enhanced Emotional Intelligence skills. The skills and capabilities of the future employees will be probably more focused on "social and emotional skills and on more advanced cognitive capabilities, such as logical reasoning and creativity" (McKinsey Global Institute, 2017; Goleman, 2000; 2005; 2007).

Furthermore, countries may help close the gap between more educated and skilled workers and those with less education and skills, reducing the skill mismatch in the labor market; investing in the quality of education programs for all social classes; expanding access to life-long learning and e-learning opportunities for all; retraining unemployed and under-skilled workers on tomorrow's technologies and promising industries' new skills; enhancing diversity and inclusion projects; and using big data analytics, machine learning, deep learning techniques, and artificial intelligence (i.e. A. I. recruiting) to accelerate global development capabilities and embracing a new paradigm of sustainability and inclusion for all (Cohen \& Kharas, 2018).

\section{CONCLUSION}

When the "Creative Destruction" wave breaks with its revolutionary innovation power on traditional and outdated business models and technological solutions it often carries with it the force to disrupt entire industries and economic and social models. The role of a wise and forward-looking international governance and regulation is not to curb or hinder innovation but to ensure that its introduction and expansion is successfully achieved while minimizing also, as much as possible, the side effects and unintended consequences on those who could be potentially harmed by the new innovation.

As explained in this paper, there are many excellent reasons to be optimistic about the promising future scenario of international business thanks to the unprecedented and exciting growth opportunities that new breakthrough innovations and technological developments will bring to firms, households, and the overall global prosperity.

The trajectory of innovation and the potential disruptive power of new business models based on Digital Transformation, A.I., Blockchain, Machine Learning, IoT, Robots, Automatic Automation, Social Network, e-commerce and Digital platforms, Drones, and other revolutionary technological devices is still hard to predict but is likely to be groundbreaking.

There are, however, already many "sound" empirical evidences across the world of the great benefits that technological innovations are having on firms' value creation and on people's social and economic inclusion. Notable examples include advancements in telemedicine; fintech, and innovative banking. Blockchain technology, digital identity, peer-to-peer value exchange and payments systems using digital wallet platforms and highly scalable payment services for many low-income unbanked individuals in emerging markets. Other successful examples also include the use of A. I. technology in agriculture and the application of drones for soil and field analysis; for decreasing planting costs; for crop spraying; for crop monitoring; for identifying parts of a field that are dry or need improvements irrigation; and for assessing crop health and for spotting bacterial or fungal infections on trees (Mazur, 2016).

Furthermore, additional examples of successful innovative business models are those based on Creating Shares Values (CSV) Strategies. Iconic examples of these strategies include: Discovery Ltd., 
a successful case of CSV strategy in the insurance industry in South Africa; Yara International, the case of a successful expansion of a fertilizer firm in Tanzania based on a CSV strategy; and the case of Nestle's adoption of a CSV strategy to develop products that improve health, nutrition, and agriculture while also increasing the productivity of small farmers involved in their value network (Porter \& Kramer, 2018).

Along with the amazing new opportunities of the likely future scenario, however, a more aggressive global competition is also likely to rise, which ultimately can be a positive boost for knowledge sharing and enhanced global professional communities' collaborations, increased R\&D investments, technological upgrading, increased productivity, improved infrastructures, and increased global trade and economic growth and prosperity, as long as fair-trade agreements will be guaranteed. This is indeed a likely scenario as long as the struggle of the major competitive forces in the global economy to achieve technological superiority, and economic, and political influence, and global dominance does not turn a potential synergic and win-win road to global prosperity into a reckless and ruthless zero-sum-game.
For this reason, it is essential that the international community, policy makers and regulators, multilateral institutions, citizens and all stakeholders continue to play a critical role in assuring that the pursuit of long-term goals of improved prosperity will bring the economic and social benefits and inclusive growth for all, through a fair global competition and a greater commitment and collaboration on R\&D, innovation, poverty reduction, sustainability projects, and CSV (Creating Shared Value) strategies. The latter ones refer to firms' strategies aiming to balance social purpose and profit goals. The international community has to remain vigilant that the race to global leadership does not turns into a self-defeating strategy for many stakeholders and for the natural environment due to potential risks associated with economic and financial instability, rising inequality, excessive risktaking, systemic risks, geopolitical tensions and conflicts among countries, and the economic consequences of short-sighted policies on climate change and global warming (i.e. related to global greenhouse gas emissions) or their impact on sustainable development and the effort to eradicate poverty.

\section{REFERENCES}

1. Atkinson, S. (2018). 10 mega trends that are (re)shaping our world. Retrieved from the World Wide Web: https://www.ipsos.com/sites/default/files/10-Mega-Trends-That-are-Reshaping-The-World.pdf

2. Buchanan, L. (2019). How 1 company -- and its insanely popular and cheap noodles -- Transformed Nigeria. Retrieved from the World Wide Web: https://www.inc.com/leigh-buchanan/clayton-christensen-prosperityparadox.html

3. Cohen, J. L., \& Kharas, H. (2018). Using big data and artificial intelligence to accelerate global development. Retrieved from the World Wide Web: https://www.brookings.edu/research/using-big-data-and-artificialintelligence-to-accelerate-global-development/

4. Christensen, C. M., \& Raynor, M. E. (2013). The innovator's solution: Creating and sustaining successful growth ( $1^{\text {st }}$ ed.). USA: Harvard Business Review Press.

5. Goleman, D. (2000). Working with emotional intelligence. New York, USA: Bantam Books.

6. Goleman, D. (2005). Emotional intelligence: Why it can matter more than IQ (10 ${ }^{\text {th }}$ ed.). New York, USA: Bantam Books.

7. Goleman, D. (2007). Social intelligence: The new science of human relationships. New York, USA: Bantam Books.

8. Hill, C. W. L., \& Hult, G. T. M. (2019). International business: Competing in the global marketplace (12 ${ }^{\text {th }}$ ed.). New York, USA: McGraw-Hill Education.

9. Kohler, T. A., Smith, M. E., Bogaard, A., Feinman, G. M., Peterson, C. E., Betzenhauser, A., ... Bowles, S. (2017). Greater post-Neolithic wealth disparities in Eurasia than in North America and Mesoamerica. Nature, 551, 619622. https://doi.org/10.1038/nature24646

10. Macleod, A. (2019). The Eurozone is in a danger zone. Posted online on Mises Wire. Retrieved from the World Wide Web: https://mises.org/wire/eurozone-danger-zone

11. Mazur, M. (2016). Six ways drones are revolutionizing agriculture. Retrieved from the World Wide Web: https://www.technologyreview.com/s/601935/six-ways-drones-are-revolutionizing-agriculture/

12. McKinsey Global Institute. (2017). Jobs lost, jobs gained: Workforce transitions in a time of automation. Retrieved from the World Wide Web: https://www.mckinsey.com/mgi/overview/2017-in-review/automation-and-thefuture-of-work/jobs-lost-jobs-gained-workforce-transitions-in-a-time-of-automation

13. Nelson, E. (2018). The \$1.3 trillion loan market that's spooking everyone right now. Retrieved from the World Wide Web: https://qz.com/1465460/the-risky-leveraged-loan-market-is-scaring-the-imf-janet-yellen-and-others/

14. OECD. (2014). Does income inequality hurt economic growth? Retrieved from the World Wide Web: https://www.oecd.org/social/Focus-Inequality-and-Growth-2014.pdf

15. OECD. (2018). A broken social elevator? How to promote social mobility. Paris: OECD Publishing. https://doi.org/10.1787/9789264301085-en

16. Pezzuto, I. (2013). Predictable and avoidable: Repairing economic dislocation and preventing the recurrence of crisis ( $\left.1^{\mathrm{st}} \mathrm{ed}.\right)$. London, UK: Routledge.

17. Pezzuto, I. (2014). Predictable and avoidable: What's next? Journal of Governance and Regulation, 3(3-1), 134150. http://doi.org/10.22495/jgr_v3_i3_c1_p7

18. Pezzuto, I. (2017). An analysis of the recent Eurozone recovery: Is it sustainable? Journal of Governance and Regulation, 6(3), 29-36. http://doi.org/10.22495/jgr_v6_i3_p3

19. Porter, M. E., \& Kramer, M. R. (2011). Creating shared value. Harvard Business Review, 89(1-2), 62-77. Retrieved from the World Wide Web: https://www.hbs.edu/faculty/Pages/item.aspx?num=39071

20. Porter, M. E., \& Kramer, M. R. (2018). Creating shared value: Competitive advantage through social impact. Retrieved from the World Wide Web: https://www.hbs.edu/

21. Romei, V. (2018). The rise of poverty among EU workers since the financial crisis - in charts. Retrieved from the World Wide Web: https://www.ft.com/content/a8d292e0-e8d9-11e8-a34c-663b3f553b35

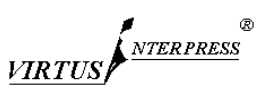


22. Schumpeter, J. A. (1911). The theory of economic development. Cambridge, USA: Harvard University Press.

23. Schwab, K. (2018). Globalization 4.0 - What it means and how it could benefit us all. Retrieved from the World Wide Web: https://www.weforum.org/agenda/2018/11/globalization-4-what-does-it-mean-how-it-will-benefiteveryone/

24. Smith, N. (2018). Why a great U.S. economy doesn't feel so great? Retrieved from the World Wide Web: https://www.bloomberg.com/opinion/articles/2018-11-09/why-a-great-u-s-economy-doesn-t-feel-so-great

25. Strauss, D. (2018). IMF faces China debt dilemma as low-income nations seek help. Retrieved from the World Wide Web: https://www.ft.com/content/6a0002ba-ecd9-11e8-89c8-d36339d835c0

26. Wade, R. H. (2013). Our misleading measure of income and wealth inequality: The standard Gini coefficient. Retrieved from the World Wide Web: http://triplecrisis.com/our-misleading-measure-of-income-and-wealthinequality-the-standard-gini-coefficient/

27. World Economic Forum (WEF). (2018). The global competitiveness report. Retrieved from the World Wide Web: https://www.weforum.org/reports/the-global-competitiveness-report-2017-2018 